\title{
AGRICULTURE
}

\section{АЕРОБНО-ТЕРМОФІЛЬНА СТАБІЛІЗАЦІЯ ПРОДУКТІВ ПРИ ПЕРЕРОБЦІ ВІДХОДІВ ТВАРИННИЦТВА}

\author{
Яремчук О. С., доктор с.-г. наук, професор \\ Вінницький національний аграрний університет, Украйна
}

DOI: https://doi.org/10.31435/rssglobal_sr/30092019/6678

\section{ARTICLE INFO}

Received 18 July 2019

Accepted 12 September 2019

Published 30 September 2019

\section{KEYWORDS}

food,

animal waste,

processing,

stabilization,

aerobic-termoplin.

\begin{abstract}
It is established that in the stool of highly productive lactating cows on the same type of feeding compared to the silage-concentrate type higher the level of OP in 1.2, crude protein and crude fat 1.6 times the calcium of 8.1 times, phosphorus - 5.9 times lower content of crude ash 1.6 times for the steadystate values of humidity index, the concentration of $\mathrm{CP}$ and crude fiber compared to animals with the silage-concentrate type of feeding.

Manure effluent of cattle breeding enterprises for intensive technologies of production are characterized by significant bacterial contamination, if hightiter, titer of Enterococcus, moisture, high content of the EO, crude protein, crude fiber, calcium, and phosphorus, have low density and viscosity, containing residues of antibacterial agents, anthelmintic and hormones.

Based on the research of the process of aerobic-thermophilic stabilization of biomass developed a new method of increasing the efficiency of bio fermentation waste, which reduces the duration of their maturation and improves the quality of organic fertilizers. The use of the drug "Oxidine" in the processing of solid cattle manure and droppings of laying hens and shortens the composting $2.0-2.4$ times, the loss of nitrogen by the biomass is 1.5 times the organic matter -1.3 times, and supplements "of Bolgen G-40" in the processing of liquid manure of pigs humidity $94 \%$, respectively 1.8 and 2.0 times.
\end{abstract}

Citation: Яремчук О. С. (2019) Aerobno-Termofilna Stabilizatsiia Produktiv pry Pererobtsi Vidkhodiv Tvarynnytstva. Science Review. 7(24). doi: 10.31435/rsglobal_sr/30092019/6678

Copyright: (ㅇ 2019 Яремчук О. С. This is an open-access article distributed under the terms of the Creative Commons Attribution License (CC BY). The use, distribution or reproduction in other forums is permitted, provided the original author(s) or licensor are credited and that the original publication in this journal is cited, in accordance with accepted academic practice. No use, distribution or reproduction is permitted which does not comply with these terms.

Постановка проблеми. Сталий розвиток галузі тваринництва як складової народногосподарського комплексу держави грунтується на широкому використанні інтенсивних технологій виробництва продукції за дотримання нормативів та гігієнічних вимог i правил щодо оптимізації умов утримання $[4,5]$, годівлі $[2,3,11,12]$, догляду та експлуатації тварин i птиці, забезпечення здоров'я i збереження поголів'я [17, 19], але й охороні навколишнього середовища від забруднень відходами тваринницьких підприємств $[15,20]$.

Накопичення на територіях підприємств великої кількості відходів тваринництва, а саме гною, гнойових та технологічних стоків, посліду забруднює грунти, водні об'єкти та повітряний басейн шкідливими газами, мікроорганізмами, пилом та іншими продуктами розщеплення органічних речовин відходів, що $є$ головною проблемою на шляху створення великих комплексів з виробництва продукції тваринництва.

Актуальність теми. Отже, розвиток галузі тваринництва тісно пов'язаний із запровадженням новітніх технологій виробництва продукції, що, крім економічної вигоди, поглиблює екологічні проблеми, пов'язані із концентрацією поголів'я та накопиченням значної кількості екскрементів і технологічних стоків на обмежених територіях $[5,18]$. 
Значна кількість екскрементів тварин та відходів підприємств 3 інтенсивними технологіями виробництва продукції тваринництва в багатьох випадках переважає конверсійну здатність грунтів та води, забруднює повітря токсичними речовинами, мікроорганізмами, пилом, посилює екологічний тиск тваринницьких об'єктів на довкілля $[15,16]$.

Дослідженнями показано, що ефективність переробки гнойових стоків при застосуванні біотехнологічних методів перетворення органічної речовини (ОР) забруднень залежить від хімічного складу, фізико-механічних властивостей відходів, що визначають кінетику та стехіометрію процесу біоферментації.

Аналіз останніх досліджень і публікацій. Значна кількість підприємств з виробництва продукції тваринництва на яких в якості відходів утворюється рідкий та напіврідкий гній, для ïx переробки застосовує переважно біологічні методи очищення. На сьогодні запропоновано i використовується значна кількість різних способів переробки, обробки і утилізації цих відходів $[8,17]$.

Необхідність зменшення об'ємів утворених відходів, або їх повна ліквідація, визначається перш за все тим, що на сьогоднішній час економічний і розвиток галузі не дозволяє забезпечити їх повну переробку. В той же час накопичення значної кількості відходів на фермах і комплексах вимагає для їх переробки відведення все більше земельних угідь, а також значних капіталовкладень 3 метою запобігання забруднення навколишнього середовища. Існуючі способи їх обробки, переробки та утилізації не завжди є ефективними, що створює загрозу забруднення навколишнього середовища і може привести до небажаних наслідків.

У зв'язку з цим існує нагальна необхідність в розробці сучасних або вдосконалення існуючих способів переробки відходів тваринництва, які б забезпечували отримання кінцевих продуктів, безпечних у санітарному відношенні і не приводили до повторного забруднення довкілля [14].

Найперспективнішими в плані переробки різних відходів тваринницьких об'єктів є біологічні способи, засновані на використанні бродильних процесів під дією мікроорганізмів гною. Переважна більшість цих процесів досліджена і використовується, але і значна частина залишається поза увагою дослідників. Процес перетворення органічної речовини (забруднень) відходів може перебігати за анаеробних та аеробних умов, має багато спільного, але завершується утворенням різних кінцевих продуктів [14].

Аеробні процеси відбуваються в біомасі за участю кисню повітря і покладено в основу різних способів їх переробки. Водночас це надійні способи їх знезараження за рахунок дії високої температури. Не дивлячись на те, що втрата певної кількості органічної речовини знижує якість одержаного продукту - органічних добрив. Тому дослідження 3 пошуку оптимальних рішень щодо перебігу процесів аеробного окислення органічних речовин у біомасі і іiі хімічним складом, впливом різних факторів на перетворення відходів привертають увагу значної кількості дослідників. Зокрема було встановлено, що одним із найдієвіших засобів досягнення найвищої ефективності процесу є аеробно-термофільна стабілізація біомаси при переробці відходів [13].

Для реалізації аеробно-термофільної стабілізації біомаси при переробці відходів запропоновано цілий ряд способів $[6,7]$ і апаратурно-технологічних рішень.

Процес аеробної стабілізації відходів перебігає з утворенням значної кількості органічних кислот i завершується утворенням енергії та цілого ряду низькомолекулярних продуктів їх розпаду: $\mathrm{CO}_{2}, \mathrm{H}_{2} \mathrm{O}, \mathrm{NO}_{3}^{-}$. Вуглець та азот цих сполук використовуються бактеріями для свого росту. За аеробних умов швидкість розпаду органічної речовини відходів значно вища, ніж за анаеробного зброджування. Одержані органічні добрива після аеробної біоферментації відходів за санітарно-гігієнічними показниками вигідно відрізняються від продуктів перетворення біомаси за анаеробних умов. Так, величина БСК 5 мулової води за аеробної стабілізації відходів становить 50-500 мг/л, що в перерахунку на 1 г беззольної речовини значно менше, ніж за анаеробного зброджування біомаси. За аеробного окислення відходів практично відсутній запах, який створюють шкідливі гази аміак та сірководень, що знижує негативний вплив відходів на навколишнє середовище. Однак здатність до фільтрації біомаси відходів за аеробного окислення нижча, ніж за анаеробного зброджування. Слід також відмітити, що затрати енергії на забезпечення процесів аеробного окислення вищі, ніж за анаеробного бродіння [17-20].

На основі проведених досліджень було з'ясовано, що аеробній стабілізації можуть бути піддані неущільнені та ущільнені (не більш як 6 годин) активний мул, сирий осад та їх суміші, які утворюються при переробці відходів тваринництва. Швидкість розпаду органічної речовини 
відходів залежить від часу аерації і в основному закінчується для не ущільненого мулу за 7-10 діб, а для ущільненого - за 10-15 діб (за температури $+20^{\circ} \mathrm{C}$ ) $[19,20]$. Суттєвий вплив на ступінь розпаду органічної речовини відходів здійснюють температура суміші та біогенні добавки. Для забезпечення процесу особливого значення також надають витратам повітря, які становлять 1-2 $\mathrm{m}^{3}$ та більше за годину на $1 \mathrm{~m}^{3}$ осаду залежно від вмісту в ньому органічної речовини.

Відстоювання або ущільнення аеробно стабілізованих осадів також впливає на швидкість бродильних процесів. Вони як правило найінтенсивніше відбуваються протягом 1-5 годин. Оскільки швидкість процесу аеробної стабілізації залежить від концентрації активного мулу інколи передбачають рециркуляцію ущільненого мулу з частковим поверненням його до стабілізатора. Одержану після завершення процесу мулову воду направляють в аеротенки. Показник БСК 5 такої води становить біля 100 мг/л, а ХСК - 360-670 мг/л [18].

Тверду фракцію (мул) після відстоювання та ущільнення при вологості 95-98,8\% в подальшому переробляють на мулових майданчиках шляхом компостування.

Встановлено, що час обробки неущільненого мулу за аеробної стабілізації відходів складає в середньому 7-10 діб. Вміст органічної речовини при цьому знижується на 20-30\%, а витрати повітря становлять $1 \mathrm{~m}^{3} / \mathrm{m}^{3}$ · год. Термін обробки суміші сирого осаду та мулу за цих умов зростає до 10-12 діб. Розпад беззольної речовини мулу при цьому збільшується до 30-40\% від загальної кількості, а витрати повітря підвищуються до 1,2-1,5 м³/год. Відстоювання стабілізованого осаду у зоні стабілізатора чи в окремому відстійнику протягом 1,5-2 години сприяє його розділенню на фракції кожна 3 яких характеризується рядом специфічних показників, які необхідні для розрахунку стабілізатора стоків [7].

Застосування аеробно-термофільної стабілізації для переробки рідкого гною показало, що процес розщеплення органічної речовини залежить від термофільних мікроорганізмів і супроводжується значним підвищенням температури суміші [19].

Отже на основі наведених даних можна зробити висновок про те, що серед існуючих способів переробки відходів тваринництва найефективнішим є метод аеробно-термофільної стабілізації осаду. Доцільність використання даного способу визначається рядом переваг над іншими методами. Це перш за все пов'язано з відносною простотою апаратурного оформлення, контролю за перебігом процесу, можливістю використання існуючих очисних споруд та обладнання різного призначення, відносно невисокими енергетичними затратами в період експлуатації і що особливо важливо - здатністю до автотермії.

Метою досліджень 3 теоретичних аспектів та розробки практичних прийомів переробки відходів тваринництва, розробка нових технологій аеробної стабілізації відходів тваринництва 3 урахуванням мезофільних та термофільних стадій процесу, впливу імобілізації живої біомаси на інертних носіях, біологічно активних добавок, а також апаратурного оформлення на якість та безпеку кінцевих продуктів переробки відходів, $\epsilon$ актуальним і важливим для вдосконалення існуючих $\mathrm{i}$ розробки нових ефективних способів переробки рідкого гною тваринницьких підприємств.

Об’єкти та методика досліджень. Дослідження з вивчення хімічного складу, властивостей екскрементів тварин, процесів перетворення органічних речовин відходів тваринницьких підприємств, вдосконалення існуючих та розробка нових способів їх переробки проведені протягом 2014 - 2019 років на базі кафедри ветеринарії, гігієни та розведення тварин Вінницького національного аграрного університету, а також в умовах ряду підприємств з виробництва продукції тваринництва. Для досліджень використовували екскременти свиней та лактуючих корів, нативні відходи та продукти їх переробки підприємств: ПАТ Племзавод «Літинський» Літинського району, ТОВ «Липовецьке» Липовецького району, Вінницької області.

Екскременти тварин та гнойові стоки відбирали у першому випадку на підприємстві 3 інтенсивною технологією виробництва молока. Продуктивність корів у середньому становила 7-9 тисяч кг молока за лактацію.

За інтенсивної технології виробництва молока лактуючих корів годували високоенергетичними кормовими сумішами. Годівля однотипова, а доступ до кормів і води вільний. Кількість обмінної енергії (ОЕ) в кормах раціону становила - 235,78 МДж, чистої енергії лактації (ЧЕЛ) - 142,88 МДж, сухої речовини - 21,45 кг, сирого протеїну (СП) - 3,73 кг, доступного протеїну (ДП) - 3,11кг, а нерозчинного протеїну (НП) - 24,8 \% від його загальної кількості.

За типової технології гній із секції приміщення видаляли за допомогою дельта-скрепера 3 наступним гідрозмивом та накопиченням у секціях гноєсховища.

Для досліджень відбирали середні проби кормів, екскрементів лактуючих корів та гнойові стоки після видалення з приміщень. У зразках визначали показники хімічного складу, 
фізичні властивості, кількість і видовий склад мікроорганізмів та наявність різних ветеринарних препаратів на основі чого здійснювали їх гігієнічну оцінку.

Відбір середніх проб екскрементів, гнойових стоків, продуктів їх переробки проводили згідно вимог. Вміст сухої речовини, вологості та золи в екскрементах тварин, гної, гнойових стоках та кормах визначали за загальноприйнятими методами $[17,19]$, а також за методиками підібраними і уточненими для відходів тваринницьких підприємств [10].

Ефективність процесу біоферментації за анаеробних умов контролювали за зміною вологості і зольності вихідної біомаси, вміст летких жирних кислот, сирого протеїну, білку, жирів, вуглеводів, органічного і неорганічного вуглецю.

При визначенні вмісту вуглеводів у вихідній і збродженій біомасі використовували метод розділення полісахаридів за ступенем їх гідролізу кислотами і визначенні редукованого цукру за Бертраном. Для визначення загального і органічного вуглецю використовували стандартний аналізатор марки АН-2579.

У стоках визначали загальне мікробне число і загальну кількість анаеробів активного мулу, колі-титр та титр ентерокока [ICO 8199:1988; ICO 9998] [1]. Проби стоків до і після очистки, а також активного мулу висівали на селективні середовища $[1,18]$.

Чисельність мікроорганізмів у пробах на рідких середовищах контролювали за методом Мак-Креді, а на твердих - шляхом підрахунку числа колоній вирощених у чашках Петрі [1].

Статистичну обробку одержаних результатів здійснювали за допомогою спеціальної програми в M. Excel, використовуючи критерій вірогідності Стьюдента [9].

Результати досліджень. Процес аеробно-термофільної стабілізації біомаси, в основному, завершується на другу добу (рис. 1-4). Як видно з наведених профілів, стабілізація температури гнойових стоків, які піддавали біоферментації за аеробних умов на рівні $50^{\circ} \mathrm{C}$, сприяла швидшому перетворенню (окисненню) ОР (забруднень) порівняно 3 аналогічними показниками без стабілізації даного параметру процесу. 3 початку процесу вже через 1 добу його перебіг характеризувався зниженням в 1,8 рази ХСК, на другу - в 3,1 рази, на третю - у 2,7 рази і така ж закономірність спостерігалась до кінця біоферментації, який тривав до 9-ї доби. Отже, термофільна стабілізація гнойових стоків при аеробній біоферментації сприяє не тільки прискоренню окислення ОР, але як встановлено подальшими дослідженнями, змінює процеси перетворення амонійного азоту та впливає на вологість біомаси.

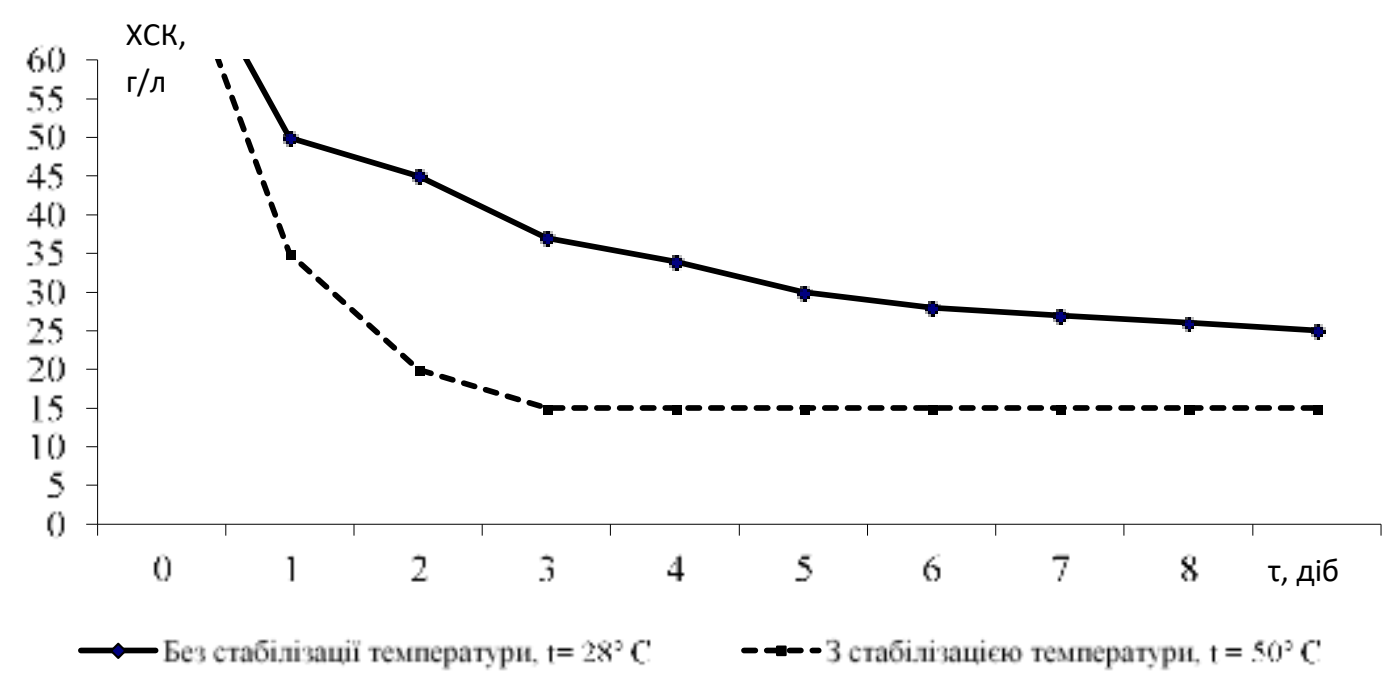

Рис. 1. Динаміка ХСК рідкого гною за аеробно-термофільної стабілізачії біомаси.

Особливої уваги при цьому заслуговують результати досліджень 3 розкладання беззольної речовини біомаси в процесі біоферментації.

Показано, що значне зниження вмісту амонійного азоту в рідкому гної за вищенаведених умов відбуваються впродовж 4 діб, а потім залишається стабільним до кінця експерименту (рис. 2). Причому ця різниця між вмістом амонійного азоту в рідкому гної за термофільної стабілізації була у період з четвертої до дев'ятої доби в 4,6 - 5,1 рази вищою, ніж без термофільної стабілізації. Одержані дані свідчать про кращу збереженість азоту за умов термофільної стабілізації рідкого гною. 


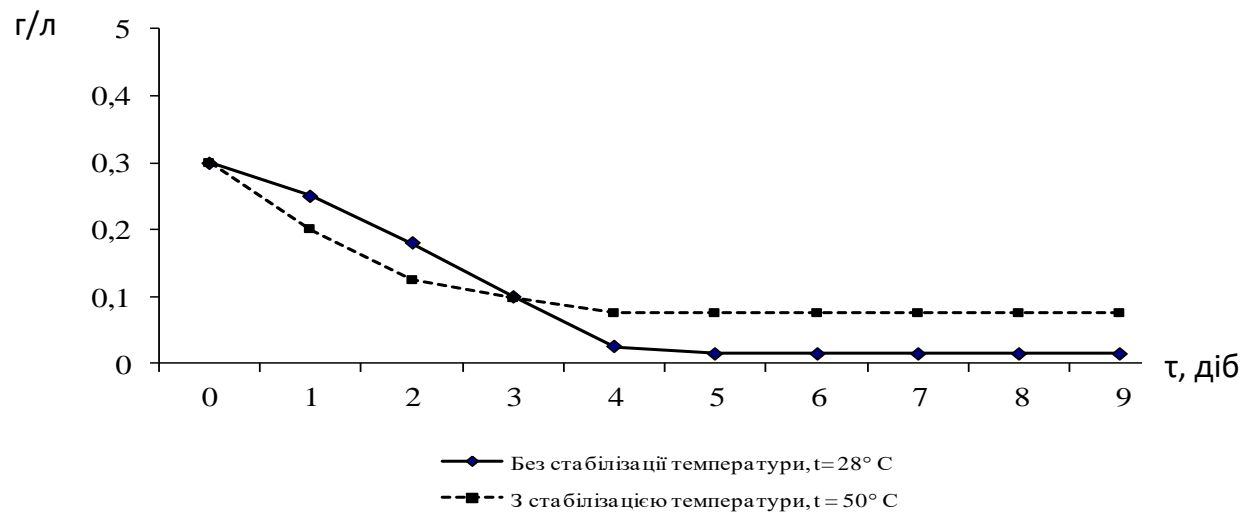

Рис. 2. Динаміка вмісту амонійного азоту рідкого гною за аеробно-термофільної стабілізаиії біомаси

Найменше аеробно-термофільна стабілізація рідкого гною в біореакторі впливає на динаміку його вологості. Встановлено незначне підвищення вологості (в межах 2,5 - 3,0\%) рідкого гною за аеробно-термофільної стабілізації біомаси порівняно 3 ії показниками без стабілізації процесу (рис. 3).

Останнє, ймовірно, пов'язано 3 підвищенням інтенсивності розпаду органічної речовини рідкого гною за умов аеробно-термофільної стабілізації біомаси (рис. 4). Так, вже через одну добу з початку процесу біоферментації зареєстровано значну різницю щодо вмісту OP в біомасі за різних умов експерименту. Встановлено, що в цей період різниця вмісту ОР в рідкому гної за аеробно-термофільної стабілізації і без неї складала близько $50-52 \%$. Ці ж відмінності були подібними для неї і в наступні періоди обробки рідкого гною. Причому у зв'язку з наявністю в осаді значної кількості органічної речовини, інтенсивність ії розкладу може досягати у випадку термофільного режиму $75-80 \%$.

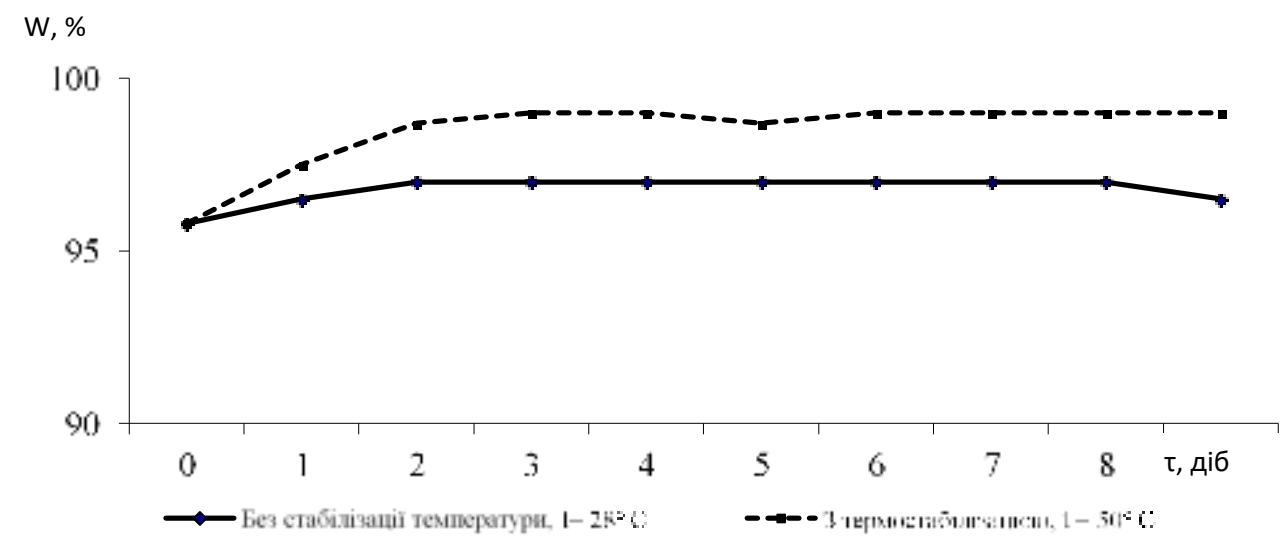

Рис. 3. Динаміка вологості рідкого гною за аеробно-термофільної стабілізаиї біомаси

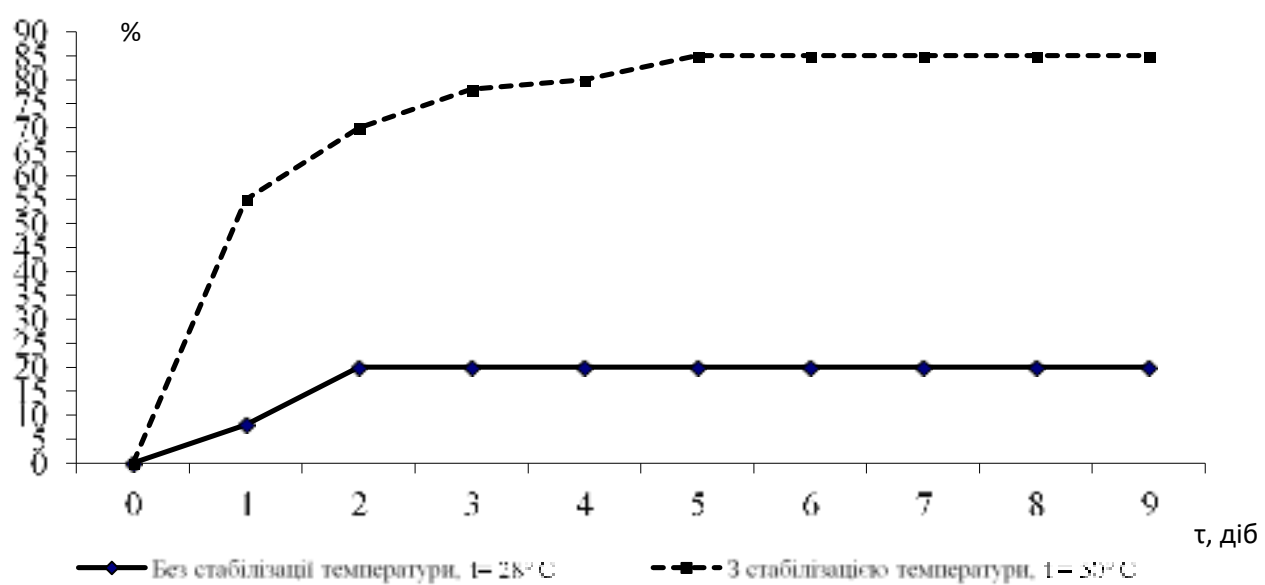

Рис. 4. Динаміка розпаду органічної речовини рідкого гною за аеробно-термофільної стабілізації біомаси 
Вважається ідеальним варіантом такий, при якому розклад органічної речовини складає $30-35 \%$ і досягає цього рівня на 8 - 15 добу. Розпад органічної речовини осаду супроводжується збільшенням його вологості в процесі стабілізації.

Перевірка одержаних даних на лабораторних моделях показала, що режим стабілізації температури гнойових токів має великий вплив на питомий опір їх вологовіддачі. За цих двох температурних режимів питомий опір вологовіддачі гнойових стоків знижується в межах від $140-180 \times 10^{-10} \mathrm{~cm} / \Gamma$ до $15-45 \times 10^{-10} \mathrm{~cm} / \Gamma$. Але якщо за термофільного режиму це досягається на 3 - 4 добу стратифікації, то за мезофільного- на 14 - 18 добу.

Встановлено, що гігієнічні показники освітленої води, одержаної після аеробнотермофільної стабілізації, практично не відрізняються від вихідних гнойових стоків. Так, ХСК був у неї на рівні $780 \mathrm{мг/л,} \mathrm{БСК} 5-85 \mathrm{мг} / л, \mathrm{NH}_{4}{ }^{+}-43,4$ мг/л, $\mathrm{PO}_{4}^{-3}-1,6$ мг/л, ЗВД $-1,15$ г/л. Виходячи з одержаних даних, освітлені стоки можуть бути направлені на біологічну очистку шляхом біоферментації в аеротенках.

Процес біоферментації органічної речовини гнойових стоків, в тому числі сирого протеїну, жиру та клітковини за аеробних умов різними групами мікроорганізмів супроводжується утворенням значної кількості тепла.

Аналізуючи одержані дані, виявлено ряд особливостей перебігу процесу біоферментації рідкого гною та вказано на залежність температури біомаси від активності термофільних бактерій. Дослідженнями також встановлено, що інтенсивність процесів термогенезу при біоферментації рідкого гною визначається, головним чином, вмістом органічної речовини i залежить від вологості вихідної біомаси.

Встановлено, що температура біомаси при біоферментації рідкого гною свиноферми за аеробних умов і вологості $92 \%$ через 12 годин перебігу процесу, порівняно з вихідними даними, практично не змінюється, а через 1 добу підвищується в 2,1 рази, через 1,5 - в 2,5 і через 2 - в 3,1 рази, а потім поступово знижується до 36 і $17^{\circ} \mathrm{C}$ відповідно через 72 та 84 години.

Подібну закономірність щодо зміни температури біомаси в процесі ії біоферментації за аеробних умов встановлено і для рідкого гною за вологості 96\%. У вищевказані часові терміни температура біомаси в процесі біоферментації також зростала, але меншою мірою, ніж за вологості $92 \%$.

Однак, не дивлячись на різну вологість гнойових стоків, максимальна температура суміші біомаси за аеробних умов була зареєстрована на другу добу. Висока температура біомаси сприяла іï знезараженню та одержанню продуктів переробки, безпечних в санітарному відношенні.

Також встановлено, що для утворення значної кількості тепла в процесі біоферментації для забезпечення термофільного режиму біомаси вміст органічної речовини в гнойових стоках повинен бути вищим за 50 г/кг, а вологість вихідної біомаси гною повинна бути нижчою за $95 \%$.

Виявлено, що за вмісту органічної речовини в гнойових стоках біля 10 г/кг, температура біомаси становить біля $38{ }^{\circ} \mathrm{C}$, збільшуючись відповідно за вмісту ОР в біомасі.

Причому, як встановлено дослідженнями, процес біоферментації біомаси рідкого гною в середньому закінчується за чотири доби. Збільшення тривалості процесу біоферментації рідкого гною за аеробних умов понад 4 доби $є$ неефективним, оскільки розпад беззольної речовини гною практично припиняється протягом вищевказаного терміну (табл. 1).

Таблиця 1. Динаміка деструкції органічної речовини рідкого гною підприємства 3 виробництва молока за аеробно-термофільної стабілізації процесу, \%, $\mathrm{M} \pm \mathrm{m}, \mathrm{n}=3$

\begin{tabular}{|l|c|c|c|c|c|c|}
\hline \multirow{2}{*}{ Показник } & \multicolumn{7}{|c|}{ Тривалість біоферментації, діб } \\
\cline { 2 - 7 } & початок & 1 & 2 & 3 & 4 & 5 \\
\hline Вологість & $94,36 \pm 1,01$ & $95,52 \pm 0,81$ & $96,58 \pm 0,61$ & $96,92 \pm 0,55$ & $97,37 \pm 0,47$ & $97,39 \pm 0,49$ \\
\hline АСР & $5,64 \pm 1,01$ & $4,48 \pm 0,81$ & $3,42 \pm 0,61$ & $3,08 \pm 0,55$ & $2,63 \pm 0,47$ & $2,61 \pm 0,49$ \\
\hline Зольність & $18,57 \pm 0,91$ & $18,9 \pm 0,8$ & $19,4 \pm 1,4$ & $20,6 \pm 0,51$ & $21,14 \pm 0,6$ & $21,14 \pm 0,81$ \\
\hline $\begin{array}{l}\text { Органічна } \\
\text { речовина }\end{array}$ & $4,56 \pm 1,83$ & $3,63 \pm 0,65$ & $2,75 \pm 0,48$ & $2,45 \pm 0,42$ & $2,07 \pm 0,36$ & $2,06 \pm 0,48$ \\
\hline $\begin{array}{l}\text { Ступінь } \\
\text { деструкції }\end{array}$ & - & 20,3 & 39,6 & 46,2 & 54,6 & 54,8 \\
\hline
\end{tabular}

Дослідженнями встановлено, що в процесі біоферментації гнойових стоків підприємства 3 виробництва молока за аеробно-термофільної стабілізації біомаси змінюється ії вологість, зменшується вміст органічної і сухої речовини та підвищується зольність продукту переробки.

Виявлено, що вміст органічної речовини рідкого гною в процесі біоферментації зменшується на другу і третю добу перебігу процесу, а в наступні дві доби залишається на однаковому рівні. 
Кількість термофільних бактерій у гної підвищується, що знижує колі-титр та титр ентерококу. Тобто, аеробно-термофільна стабілізація біомаси рідкого гною в процесі біоферментації, що досягається аерацією суміші, значною мірою покращує санітарно-гігієнічні показники продуктів іï переробки.

Таким чином, застосування аеробно-термофільної стабілізації біомаси при біоферментації рідкого гною дозволяе протягом перших двох-трьох діб, а краще 4-5 діб забезпечити повне знезараження гнойових стоків за рахунок високої температури, що $\epsilon$ результатом діяльності термофільних бактерій.

Інтенсивний розпад органічної речовини рідкого гною за участю кисню сприяє утворенню значної кількості тепла, що переводить процес біоферментації біомаси в термофільний режим, за якого максимум температури біомаси досягає значення $46-57^{\circ} \mathrm{C}$ і вище.

Особливого значення надають дослідженню біоферментації біомаси рідкого гною за проточного режиму. Встановлено, що температура біомаси в процесі біоферментації рідкого гною за проточного режиму є похідною від дози завантаження біоферментера (ступеню розбавлення) і вологості вихідної сировини (рис. 5).

Визначення санітарно-гігієнічних показників продуктів біоферментації показало, що за цих умов число мезофільних бактерій, грибів, особливо ентеробактерій зменшується, а чисельність термофільних бактерій і актиноміцетів значно зростає. За проточного режиму процесу біоферментації спостерігаються лише незначні зміни загального мікробного числа, одержаних органічних добрив. Так, при $\mathrm{D}=0,5-0,33$ діб $^{-1}$ в одержаному продукті біоферментації переважають амоніфікатори i денітрифікатори - основні деструктори органічних речовин. Збільшення часу перебування біомаси в біореакторі при $\mathrm{D}=0,2-0,16$ діб $^{-1}$ сприяє розвитку за цих умов термофільних нітрифікаторів I і II фаз.

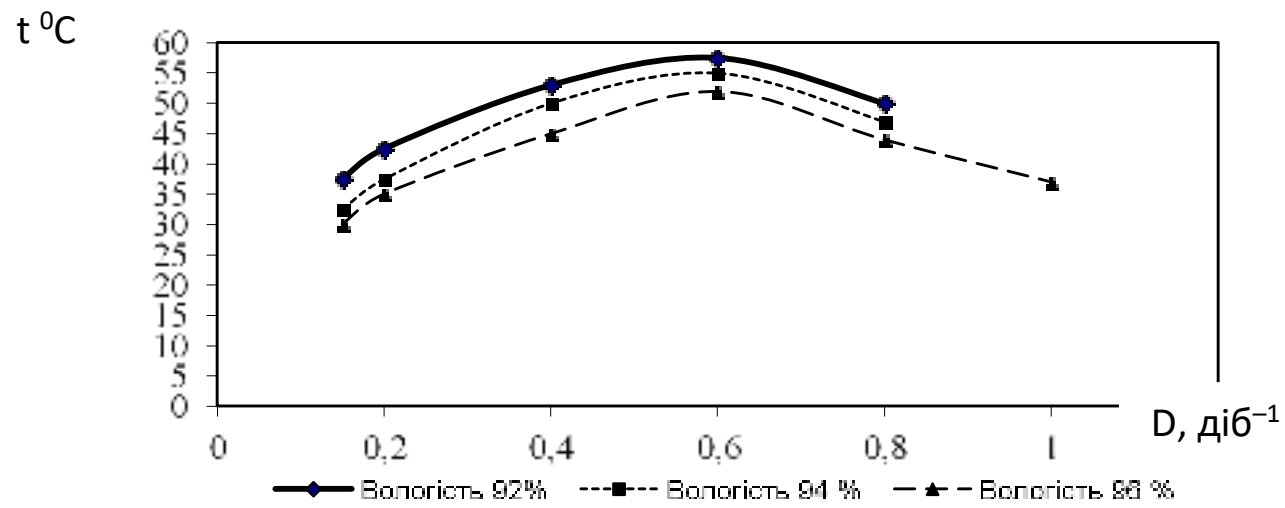

Рис. 5. Вплив вологості і ступеню розбавлення вихідної біомаси на температуру суміші в процесі біоферментаиії за проточного режиму.

Дослідженнями також встановлено, що у рідкому гної, обробленому за аеробнотермофільних умов, при його подальшій біоферментації спостерігається висока інтенсивність процесів нітрифікації (табл. 2).

При цьому у продуктах переробки зменшується вміст органічних забруднень. Про це свідчить зниження на $80 \%$ ХСК та на $88 \%$ БСК 5 рідкого гною після біоферментації. Не дивлячись на те, що загальний ефект процесу нітрифікації в цілому незначний, вміст нітратного азоту від загальної кількості окисленого складає 59 \%. Подібні результати було також отримано і при обробці рідкого гною великої рогатої худоби.

Таблиця 2. Показники процесу нітрифікації рідкого гною, попередньо обробленого за аеробно-термофільних умов, г/л, $\mathrm{M} \pm \mathrm{m}, \mathrm{n}=3$

\begin{tabular}{|c|c|c|}
\hline \multirow{2}{*}{ Показники } & \multicolumn{2}{|c|}{ Рідкий гній } \\
\cline { 2 - 3 } & до біоферментації & після біоферментації (мезофільні умови) \\
\hline $\mathrm{XСК}$ & $3,3 \pm 0,14$ & $0,66 \pm 0,08^{*}$ \\
\hline БСК & $0,43 \pm 0,02$ & $0,013 \pm 0,001^{*}$ \\
\hline $\mathrm{N}_{\text {заг. }}$ & $0,48 \pm 0,04$ & $0,16 \pm 0,01^{*}$ \\
\hline $\mathrm{NH}_{4}{ }^{-}$ & $0,63 \pm 0,03$ & $0,27 \pm 0,02^{*}$ \\
\hline $\mathrm{NO}_{2}{ }^{-}$ & $0,001 \pm 0,001$ & $0,124 \pm 0,003^{*}$ \\
\hline $\mathrm{NO}_{3}{ }^{-}$ & 0 & $0,239 \pm 0,022^{*}$ \\
\hline $\mathrm{P}_{\text {заг. }}$ & $0,12 \pm 0,004$ & $0,0062 \pm 0,001^{*}$ \\
\hline
\end{tabular}


Вміст нітритів і нітратів у стабілізованій біомасі значно збільшується порівняно із вихідним гноєм, а утворений в результаті біоферментації продукт $є$ дезодорованим i знезараженим органічним добривом.

Встановлено, що хімічний склад рідкого гною після біоферментації в автотермічному режимі та отриманих з нього органічних добрив, за вмістом органічної речовини, загального азоту та загального фосфору відповідав встановленим вимогам (табл. 3).

Таблиця 3. Показники хімічного складу рідкого гною та продуктів його біоферментації, \%, $\mathrm{M} \pm \mathrm{m}, \mathrm{n}=3$

\begin{tabular}{|l|c|c|c|}
\hline \multicolumn{1}{|c|}{ Тип продукту } & $\begin{array}{c}\text { Органічна } \\
\text { речовина }\end{array}$ & Загальний азот & Загальний фосфор \\
\hline Рідкий гній & $81,5 \pm 2,4$ & $3,2 \pm 0,26$ & $2,35 \pm 0,12$ \\
\hline Біомаса (орг. добрива) & $76,1 \pm 3,4$ & $3,65 \pm 0,42$ & $3,55 \pm 0,42$ \\
\hline Вимоги стандарту & не $<40$ & не $<1,6$ & не $<0,6$ \\
\hline
\end{tabular}

Комплексний аналіз процесу біоферментації рідкого гною за аеробно-термофільної стабілізації показав, що в ньому інтенсивно відбувається мінералізація органічної речовини, а утворене тепло достатнє для забезпечення процесу біоферментації в автотермічному режимі.

При наступній стадії процесу біоферментації за мезофільних умов завершується процес мінералізації органічної складової забруднень, на що вказує збільшення кількості рухомих форм біогенних елементів.

Виходячи із аналізу одержаних результатів експериментальних досліджень, було запропоновано наступну структурно-функціональну схему процесу аеробно-термофільної стабілізації рідкого гною (рис. 6).

система аерації і перемішування

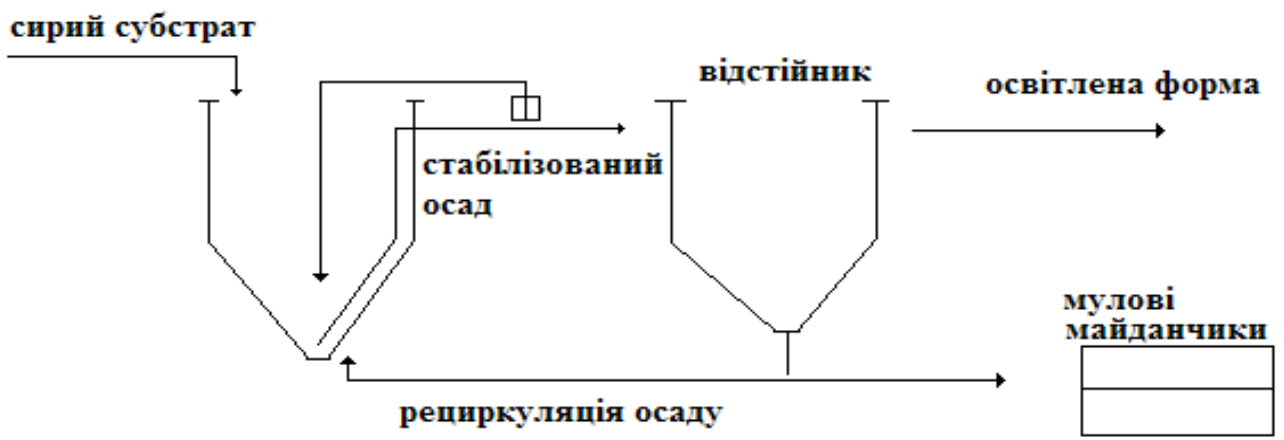

Рис. 6. Принципова структурно-функціональна технологічна схема аеробно-термофільної стабілізачії осаду рідкого гною.

Характеризуючи дану схему, слід зазначити, що рідкий гній (субстрат) поступає по трубопроводу із заданою витратою до ємності для аеробно-термофільної стабілізації. Стабілізований осад під гідростатичним напором через трубопровід опорожнення відводиться 3 ємності у відстійник. Процес аеробної стабілізації біомаси забезпечується роботою струменевої системи аерації і блоку ерліфтів.

Струменева аераційна система працює на базі насосу ФГ 450/22,5, а робота ерліфтів забезпечується компресором.

Стабілізований осад підлягає відстоюванню у відстійнику, у процесі якого проходить його розділення на освітлену рідину і ущільнений осад. Хімічний склад освітленої рідини, що приведений вище, дозволяє направляти ії на очистку у аеротенки шляхом біоферментації.

Слід відмітити, що, враховуючи вологовіддаючу властивість осаду, його успішно можна зневоднювати на вакуум-фільтрі або на мулових майданчиках.

Таким чином, рідкий гній підприємств з виробництва свинини і молока, отриманий за гідравлічних систем гноєвидалення при вологості $92-96 \%$ доцільно піддавати аеробній біоферментації в автотермічному режимі, в результаті чого покращуються органолептичні, фізико-хімічні властивості і підвищується їх цінність як органічних добрив.

Висновки. Серед існуючих способів переробки відходів тваринництва найефективнішим $\epsilon$ метод аеробно-термофільної стабілізації осаду. Доцільність використання даного способу визначається рядом переваг над іншими методами. Це перш за все пов'язано з відносною 
простотою апаратурного оформлення, контролю за перебігом процесу, можливістю використання існуючих очисних споруд та обладнання різного призначення, відносно невисокими енергетичними затратами в період експлуатації і що особливо важливо - здатністю до автотермії.

1. Склад та властивості калових мас підсисних свиноматок, поросят на відлученні та свиней на відгодівлі за концентратного типу годівлі характеризуються високою вологістю $(93,8-95,3 \%)$, низьким рівнем СР $(4,7-7,2 \%)$ та високим вмістом сирого протеїну, БЕР, сирої клітковини і золи, а також значною кількістю неперетравлених решток корму з розміром часток 0,25 мм і менше.

2. Приріст біомаси активного мулу і споживання кисню в системах біологічної очистки гнойових стоків залежить від швидкості розбавлення і коефіцієнта рециркуляції активного мулу. Ефективність вилучення забруднень із стічних вод є величиною постійною і за швидкості розбавлення $\mathrm{D}=0,01 \ldots 0,1$ год. $^{-1}$ становить від 85 до $95 \%$ за ХСК і БСК.

3. Елімінація забруднень стічних вод симбіотичним мулом залежить від тривалості процесу, а одержана рідка фракція за ХСК і БСК 5 , вмістом амонійного азоту, фосфору, бактеріальним забрудненням i колі-титром характеризується вищою ступеню очистки порівняно з використанням активного мулу.

4. Попередня обробка біомаси шляхом аеробно-термофільної стабілізації в процесі збродження рідкого гною молочного комплексу за анаеробних умов скорочує у 6,5 - 7 разів період запуску установки, підвищує ступінь деструкції ОР до 61,8 \%, збільшує вміст метану у газовій суміші до 74,1\%, знижує кількість кислото-, спороутворюючих та протеолітичних бактерій в одержаних продуктах за відсутності бактерій групи кишкової палички.

5. Підвищення температури біомаси у біоферментері до $52{ }^{\circ} \mathrm{C}$ при збродженні гнойових стоків за анаеробних умов збільшувало ії вологість на $6,2 \%$, зольність - на $6,3 \%$, знижувало вміст ОР в 2,6, а АCP - в 2,4 рази порівняно з нативними стоками.

6. На основі експериментальних досліджень з'ясовано теоретичні аспекти застосування для переробки відходів тваринницьких підприємств біотехнологій, заснованих на здатності асоціацій мікроорганізмів активного та симбіотичного мулу перетворювати органічні сполуки та неорганічні речовини гнойових стоків за різних умов та режимів процесу біоферментації.

7. Попередня обробка гнойових стоків в аеробно-термофільному режимі та їх анаеробне збродження за мезофільних умов посилює перетворення біомаси, збільшує вихід біогазу та покращує санітарно-гігієнічні показники органічних добрив.

\section{REFERENCES}

1. Aires Rэihel M. Analyz stochnыkh vod dlia selskokhoziaistvennoho yspolzovanyia / Laboratornoe rukovodstvo po parazytolohyy y bakteryalnum metodam yssledovanyia. - M.: Medytsyna; Zheneva: VOZ 1999. - $34 \mathrm{~s}$.

2. Biotekhnolohichnyi kompleks z vyrobnytstva moloka na enerhetychno zbalansovanii ta ekolohichno bezpechnii osnovi: Rekomendatsii / I.M. Kudlai [ta in.]. - UkrNDIPVT im. L. Pohoriloho. - Doslidnytske, 2010. - 49 s.

3. Biopalyva (tekhnolohii, mashyny i obladnannia) / V.O. Dubrovin, M.O. Korchemnyi, I.P. Maslo [ta in.]. K.: TsTI „Enerhetyka i elektryfikatsiia”, 2004. $-256 \mathrm{~s}$.

4. Verbytskyi P. Vymohy Yevropeiskoho Soiuzu do pererobky vidkhodiv tvarynnoho pokhodzhennia / P. Verbytskyi, V. Vlizlo // Veterynarna medytsyna Ukrainy. - 2008. - \#6. - S. $24-26$.

5. Verbytskyi P. Utylizatsiia vidkhodiv tvarynnoho pokhodzhennia v Ukraini / P. Verbytskyi // Tvarynnytstvo Ukrainy. - 2008. - \# 5. - S. 2-4.

6. Hromozova E.Y. Opredelenye parametrov aэrobno-termofylnoho mykrobyolohycheskoho protsessa ochystky stochnыkh vod / E.Y. Hromozova, T.P. Sliusarenko, S.P. Tsыhankov // Mykrobyolohycheskyi zhurnal. - 1984. - T.46. - \# 5. - S. 12-16.

7. Daineko F.A. Yssledovanye protsessa aэrobnoi stabylyzatsyy aktyvnoho yla / F.A. Daineko, V.E.Adzhyenko, D.A. Danylovych, B.A. Ershov // Tezysы dokl. 4-y Mezhdunar. konhr. «Voda - эkolohyia y tekhnolohyia» Moskva, 30 maia - 2 yiulia 2000. - M. ЭKVATEK, 2000. - S. 497-498.

8. Datsenko I.I. Hihiiena i ekolohiia liudyny / I.I. Datsenko. - Lviv: Afisha. - 2000. - 248 s.

9. Dvoretskyi D.S. Kompiuternoe modelyrovanye byotekhnolohycheskykh protsessov y system / D.S.Dvoretskyi, S.M. Dvoretskyi. - Tambov, 2005. - 168 s.

10. Ynstruktsyia po laboratornomu kontroliu ochystnukh sooruzhenyi na zhyvotnovodcheskykh kompleksakh. / Chast II. Opredelenye byohennukh veshchestv. Analyz osadkov y yla: Normatyvno-tekhnycheskyi dokument. Mynysterstvo selskoho biodobavo SSSR; Hlavselstroiproekt; Hypronyselkhoz. - M.: Kolos, 1983, - 52 s.

11. Kochmarskyi V.Z. Biohazova tekhnolohiia utylizatsii orhanichnykh vidkhodiv - shliakh do ekonomii enerhii / V.Z. Kochmarskyi // Enerhozberezhennia Polissia. - 2001. - \# 2. - S. 4-5.

12. Krasinko V.O. Rozrobka biotekhnolohii ochystky stichnykh vod kharchovykh vyrobnytstv iz zastosuvanniam spoluk zaliza : avtoref. dys. na zdobuttia nauk. stupenia kand. tekhn. nauk: spets. / 03.00.20 "Biotekhnolohiia" / V.O. Krasinko. - K, 2004. -20 s. 
13. Lukashevych Ye. Intensyfikatsiia aerobnoho ochyshchennia stichnykh vod pidpryiemstv molochnoi promyslovosti / Ye. Lukashevych, H. Nikitin // Kharchova i pererobna promyslovist. - 1998. -\# 8. - S. 32-33.

14. Mykhaleva T.A. Prymenenye byolohycheskykh prudov dlia bezopasnoi utylyzatsyy zahriaznennыkh vod predpryiatyi APK / T.A. Mykhaleva, O.N. Rodianova // Эkosystemы, ykh optymyzatsyia y okhrana. 2000. - Vыр. 20. - S. 111-116.

15. Perehudov S.S. Эkolohycheskye trebovanyia k predpryiatyiam po proyzvodstvu svynynы. Problemы yspolzovanyia navoznыkh stokov v svynovodcheskykh predpryiatyiakh / S.S. Perehudov // Efektyvne tvarynnytstvo. $-2010 .-\# 4$. - S. 41-43.

16. Piskun V.I. Teoriia stvorennia resursooshchadnykh tekhnolohii obrobky stokiv / V.I. Piskun // Visnyk ahrarnoi nauky. - 2002. - \#8. - S. 52-54.

17. Yaremchuk O.S. Teoretychni aspekty protsesu fermentatsii vidkhodiv tvarynnytskykh pidpryiemstv / Yaremchuk O.S., Zakharenko M.O., Kovalenko V.O. // Zbirnyk naukovykh prats Vinnytskoho NAU. 2009. - Vyp. 40, t. 1. - S. $119-128$.

18. Yaremchuk O.S. Zastosuvannia aeratsii v protsesakh biofermentatsii vidkhodiv tvarynnytskykh pidpryiemstv / Yaremchuk O.S., Zakharenko M.O., Kovalenko V.O. // Bioresursy i pryrodokorystuvannia. - 2010. - T. 2, \# 3-4. - S. $83-87$.

19. Yaremchuk O.S. Sanitarno-hihiienichni aspekty protsesu anaerobnoi biofermentatsii vidkhodiv tvarynnytstva / Yaremchuk O.S. // Zbirnyk naukovykh prats Vinnytskoho NAU. - 2012. - Vyp. 1 (57). - S. 157 - 163.

20. Yaremchuk O.S. Sanitarno-hihiienichni pokaznyky produktiv biofermentatsii vidkhodiv tvarynnytskykh pidpryiemstv za aerobno-termofilnoi stabilizatsii biomasy / Yaremchuk O.S., Zakharenko M.O., Poliakovskyi V.M., Kovalenko V.O. // Visnyk Zhytomyrskoho natsionalnoho ahroekolohichnoho universytetu. - 2012. - \# 2 (33), t. 2. - S. $165-171$. 